\title{
The Status of Ambassadors in Lucas de Penna's Commentary on the Tres Libri*
}

\author{
Dante Fedele \\ KU-Leuven, Law Faculty
}

\section{Introduction}

In recent historiography, the contribution of medieval canon law to the formation of international law has frequently been pointed out. A direct influence on treaty law has been particularly noted, but it has also been argued that the scholarship on embassies and on ambassadors is rooted in canon law and was elaborated by ius commune jurists based on the de officio legati section in the Liber Extra (1234) ${ }^{1}$. Although pontifical diplomacy and the specialization of the functions of papal legates had seen a remarkably rapid development from the mid $11^{\text {th }}$ century onwards, it was only after the publication of Gregory IX's collection that the figure of the papal legate became the subject of serious doctrinal elaboration, exemplified by Henricus de Segusio's Summa, finished in 1253, and by Guillaume Durand's Speculum legatorum, written in 1278-1279 and afterwards included in the Speculum iudiciale ${ }^{2}$. Both the papal bulls, with which legates were despatched, and these major doctrinal works have therefore been the object of studies, many of which discuss the legal and ecclesiological nature of the papal legate, defining his role and functions and establishing the extent of his powers ${ }^{3}$.

\footnotetext{
* I wish to thank Professor Alain Wijffels for his comments and helpful suggestions.

${ }^{1}$ See R. Fubini, L'ambasciatore nel XV secolo: due trattati e una biografia (Bernard de Rosier, Ermolao Barbaro, Vespasiano da Bisticci), Mélanges de l'École française de Rome. Moyen-Age, 108/2 (1996), p. 645. More generally, see J. Muldoon, The Contribution of the Medieval Canon Lawyers to the Formation of International Law (1972), in: Id., Canon Law, the Expansion of Europe, and World Order, Aldershot 1998; and R. Lesaffer, The Influence of the Medieval Canon Law of Contract on Early Modern Treaty Law, in: Proceedings of the Eleventh International Congress of Medieval Canon Law, Catania, 30 July-6 August 2000, ed. by M. Bellomo, Città del Vaticano 2006, p. 449-470.

${ }^{2}$ See Henricus de Segusio, Summa aurea, Venetiis, [n.p.], 1574 [reprint Torino 1963], liber I, rubrica De officio Legati, col. 317-329, and K. Pennington, Henricus de Segusio (1993), in: Id., Popes, Canonists and Texts, 1150-1550, Aldershot 1993. See also Gulielmus Durandus, Speculum iudiciale, Basileae, apud Ambrosium et Aurelium Frobenios fratres, 1574 [reprint Aalen 1975], liber I, particula I, rubrica De Legato, p. 29A-58B and, on the origins of this text, C.I. Kyer, The Legation of Cardinal Latinus and William Duranti’s «Speculum Legatorum», Bulletin of Medieval Canon Law, 10 (1980), p. 56-62.

${ }^{3}$ See R.C. Figueira, The Medieval Papal Legate and his Province: Geographical Limits of Jurisdiction, Apollinaris, 61 (1988), p. 817-860; Id., «Legatus apostolicae sedis»: the Pope's "alter ego» According to Thriteenth-Century Canon Law, Studi Medievali, 27/2 (1986), p. 527-574; and Th. Boespflug, La représentation du pape au Moyen Âge. Les légats pontificaux au XIII siècle, Mélanges de l'École française de Rome. Moyen Âge, 114/1 (2002), p. 59-71. On the use of diplomacy from the $11^{\text {th }}$ century
} 
In contrast, the civil law scholarship on the secular ambassador has been almost entirely ignored by historiographers, even though it was crucial to the conceptualization of the diplomatic function at the end of the Middle Ages, and in the discussion of many of its aspects ${ }^{4}$. The importance of this lacuna is all the more significant given the clear differences between the figures of the papal legate and of the secular ambassador. The latter - sent abroad and thus beyond the territorial limits of the power of his principal was an agent without any jurisdiction, whereas the legate was an agent of government sent by the pope (whose iurisdictio claimed universality) to perform tasks of territorial administration. This is why, for example, the ambassador's negotiating powers were determined by ius commune jurists referring not to the papal legate's delegated jurisdiction, but to the mandate of private law ${ }^{5}$. It is no accident, given this difference, that the literature on the papal legate and that on the secular ambassador developed along distinct and parallel lines through the Middle Ages and the early-modern age: each branch was faced with specific problems. As a result, they each developed their own distinct characteristics ${ }^{6}$.

This gap in legal historiography needs to be filled with a detailed study of the scholarship on ambassadors which developed within ius commune literature and, at least since the end of the $12^{\text {th }}$ century, accompanied the development of embassies in Italian political life ${ }^{7}$. This doctrinal debate was a rich one. The very nature of the office of ambassador - defined, according to Justinian's texts, as an officium and a munus publicum - was held up for investigation, as were its various institutional and material aspects. That included, for example, the right to send ambassadors; their appointment and the factors accepted as exempting someone from the duty to serve on a mission; their

onwards as a tool for centralizing Church government within the framework of the Gregorian reforms, see also W. Ullmann, The growth of Papal Government in the Middle Ages, 3 ed., New York 1970, p. 291-292, K. Pennington, Johannes Teutonicus and papal legates (1983), in: Id., Popes, Canonists and Texts (supra, n. 2), and more recently K.R. Rennie, Law and Practice in the Age of Reform. The Legatine Work of Hugh of Die (1073-1106), Turnhout 2010.

${ }^{4}$ The only exception is D.E. Queller, The Office of Ambassador in the Middle Ages, Princeton 1967 who does not, however, mention Lucas de Penna's commentary on the Tres Libri, which is the subject of this paper.

${ }^{5}$ See D. Fedele, Naissance de la diplomatie moderne. L'ambassadeur au croisement du droit, de l'éthique et de la politique, $\mathrm{PhD}$ dissertation, ENS de Lyon, december 2014 (awaiting publication), part I, chap. 2 and 3 .

${ }^{6}$ See the catalogue of texts drawn up by V. Hrabar in his De legatis et legationibus tractatus varii, Dorpat 1906, and in his De legatorum jure tractatuum catalogus completus ab anno MDCXXV usque ad annum $M D C C$, Dorpati Livonorum (Jurjev) 1918. Imperial legates sent on missions during the Middle Ages may require a specific study: for an overview see Aus der Frühzeit europäischer Diplomatie: zum geistlichen und weltlichen Gesandtschaftswesen vom 12. bis zum 15. Jahrhundert, hrsg. C. Märtl und C. Zey, Zürich 2008, especially the introduction.

${ }^{7}$ On the statutes of these cities regarding ambassadors, see at least S. Angelini, La diplomazia comunale a Perugia nei secoli XIII e XIV, Firenze 1965; D.E. Queller, Early Venetian Legislation on Ambassadors, Genève 1966; and R. Fubini, Diplomazia e governo in Firenze all'avvento dei reggimenti oligarchici, in: Id., Quattrocento fiorentino. Politica, diplomazia, cultura, Pisa 1996, p. 11-98. 
salary and the reimbursing of expenses or compensation for losses suffered during a mission; their obligation to promote the public interest entrusted to them - rather than their own, or that of any third party; the immunities and privileges to which they were entitled and, finally, the extent of their negotiating powers ${ }^{8}$. Moreover, it is known that most of the ius commune jurists working in Italy at the end of the Middle Ages both taught and took an active part in the political life of the cities where they lived, assuming different public offices, including that of ambassador ${ }^{9}$ : this meant that they often had direct experience of both the importance of embassies for the Italian cities and of the urgency of the issues which they raised.

Naturally, a number of challenges arise when attempting an accurate analysis of this debate because jurists, aware that the libri legales contained comparatively few rules concerning the ambassador, understood early on the need to borrow principles and concepts from other areas; they made an extensive use of analogical reasoning and took a flexible, innovative approach, adapting principles formulated in the Justinian's texts on questions of mandate, society, guardianship, marriage and succession, and extending them to the ambassador. The above questions are therefore often dealt with throughout the commentaries in various parts of the Corpus iuris civilis, not just in the sections de legationibus of the Digest and the Code. It is important to highlight that characteristic methodological feature of late-medieval doctrine, because it is one of the cornerstones of that literature - usually referred to as the «treatises on the ambassador» - which, from the $15^{\text {th }}$ century on, focused on the figure and the activities of the diplomat ${ }^{10}$. Notwithstanding the challenges it presents, the mapping of the medieval legal sources on the ambassador can be seen as essential to a clear, accurate evaluation of the selection and filtering carried out by scholars at the time and during the following centuries ${ }^{11}$.

This paper is a contribution to such an analysis. It deals with a work of great interest: Lucas de Penna's commentary on the Tres Libri Codicis and, in particular, the part in which the title de legationibus (Cod. 10.65(63)) is discussed ${ }^{12}$. Other jurists had

\footnotetext{
${ }^{8}$ For an insight into this debate, see D. Fedele, Naissance (supra, n. 5), part I, chap. 1, 3 and $4 \S 1$, as well as part II, chap. $3 \S 1$.

${ }^{9}$ See ibidem, Introduction, p. 22-25 for references.

${ }^{10}$ This paper is a revised version of a part of my PhD dissertation (cit. supra, n. 5), which deals with this body of texts. For a discussion of the problems linked to its definition, see also J.-C. Waquet, Les écrits relatifs à l'ambassadeur et à l'art de négocier: «un genere di riconoscibile omogeneità»?, in: De l'ambassadeur. Les écrits relatifs à l'ambassadeur et à l'art de négocier du Moyen Âge au début du XIX siècle, éd. par S. Andretta, S. Péquignot et J.-C. Waquet, Rome, 2015, p. 9-31. I thank Professor Waquet for allowing me to read his paper before its publication.

${ }^{11}$ This problem was raised by A. Wijffels, Le statut juridique des ambassadeurs d'après la doctrine du XVI siècle, Publication du Centre européen d'Études bourguignonnes (XIV ${ }^{\mathrm{e}}-\mathrm{XVI}^{\mathrm{e}}$ siècles), 32 (1992), p. 127-142.

12 For Lucas de Penna's biography, as well as M. Mercedes Mercedes Wronowski, Luca da Penne e l'opera sua, Pisa 1925, see E. Conte, s.v. Luca da Penne, Dizionario Biografico degli Italiani, vol. 66, Roma 2007, p. 251-254. Born in Penne, in Abruzzo, at the beginning of the $14^{\text {th }}$ century, Lucas studied law in Naples. He does not seem ever to have taught, but he held many public offices, both in Naples and in central Italy. Appointed as a papal secretary, he lived in Avignon in the 1370s, before returning to Italy. He
} 
already based their studies of the ambassador on the same section, as evidenced by the Summae on the Tres Libri drawn up between the $12^{\text {th }}$ and $13^{\text {th }}$ centuries by Pillius de Medicina and Rolandus de Lucca: they had both, thanks to a dense network of references to numerous passages in the libri legales (and therefore separately from the coeval canonical doctrine on the papal legate), started to structure the subject matter, anchoring it - in the case of Rolandus - explicitly in real contemporary experience ${ }^{13}$. Nevertheless, Lucas' Commentaria have some very special characterics which make it unique in latemedieval legal literature. Before engaging with the actual commentary on Justinian's text, Lucas not only discusses at great length the institutional and material aspects of embassy - as do other, both contemporary and previous, jurists - but also analyses the qualities and the behaviour of the ambassador himself. This first part is completely unconnected to the constitutions collected in the title de legationibus and appears to be a reflection made «iuxta formulam intellectus» ${ }^{14}$. In it Lucas first sets out a list of twenty objective, cultural and moral qualities («qualitates»), then another list of twenty precautions («cautelae»), some of which regard the effective behaviour of the ambassador and the speaking technique which he must use in order to achieve his objectives $^{15}$. The method which Lucas adopts for this investigation also strikes us as being of particular interest: while the commentary on the imperial constitutions combines a lexical analysis and an erudite, even "antiquarian" one, the discussion of the qualitates and the cautelae relevant to the ambassador refers frequently, on the one hand, to the classical figure of the orator as described by Cicero and others and, on the other, and even more frequently, to the precepts for the clergy laid down in the theological and canonical literature. This is a highly innovative approach, not only in its heavy use of classical sources, which has led to scholars sometimes labeling Lucas as a «humanist» ${ }^{16}$, but, to an even greater extent, because of his recourse to principles developed for other office holders, which had already been carefully elaborated, to find a basis upon which to discuss the necessary qualities, training and ethics for an ambassador in the carrying out of his own officium. And if in the actual commentary on Justinian's text an interest in the institutions and administration of the Romans predominates, to the extent that any links with the present are sometimes hard to discern, the observations discussed in this first

is believed to have died in Penne in 1390. The work on his Commentaria, begun in 1348, continued for many years, so that it is not known when it was completed.

${ }^{13}$ See E. Conte - S. Menzinger, La Summa trium librorum di Rolando da Lucca (1195-1234). Fisco, politica, scientia iuris, Roma 2012, with the complete edition of Rolandus' Summa (which included passages from the previous Summae on the Tres Libri by Placentinus and Pillius) preceded by a rich introduction.

${ }^{14}$ Lucas de Penna, Commentaria in tres posteriores libros Codicis Iustiniani, Lugduni, apud Ioannam Iacobi Iuntae F., 1582, p. 321 A, n 37.

${ }^{15}$ See ibidem, p. 311A-324B: 312A-316B for the twenty qualitates; p. 316B-320B for the twenty cautelae; p. 321A-324B for the commentary on Justinian's text.

${ }^{16}$ See W. Ullmann, The Medieval Idea of Law as represented by Lucas de Penna. A Study in FourteenthCentury Legal Scholarship, London 1946, p. VIII which, with a certain amount of exaggeration, describes Lucas' text as «the first humanistic commentary of law». 
part, in contrast, clearly manifest a desire to go beyond textual exegesis and to work on ideas of relevance to contemporary politics.

Those features show the importance of this commentary for the issues set out above. Moreover, it aroused the interest of authors who wrote during the following centuries on the ambassador's status. Apart from references to specific questions that occur here and there in the various treatises, it may be recorded that Julius Ferretus's De Oratoribus, seu Legatis principum, et de eorum fide, et officio Tractatus, published posthumously in Venice in 1563, was largely plagiarized from Lucas de Penna ${ }^{17}$, and that even in 1643, by which time the treatises on the ambassador had become a popular literary genre throughout western and central Europe, the Spanish diplomat Cristóbal de Benavente y Benavides, in his ponderous Advertencias para Reyes, Principes, y Embaxadores, refers to Lucas' commentary when considering the virtues of the ambassador $^{18}$. A closer analysis of this commentary is therefore warranted. I shall start with Lucas' investigation of the institutional and material aspects of embassies, and then examine his investigation of the qualities and behaviour of the ambassador.

\section{The institutional and material aspects of embassies}

The institutional and material aspects of embassies, discussed by many jurists from the end of the $12^{\text {th }}$ century onwards, are also dealt with in Lucas' commentary. He picks up the definition of the office of ambassador as an officium and munus publicum already formulated by medieval scholars and tries to clarify its specific features. In his opinion, this officium entails the «establishing of friendship, alliance and peace» between the sender and the recipient of a mission. The Neapolitan jurist bases this definition on a reference to the words of the constitution Ego Ludovicus, falsely attributed to Louis the Pious and collected in Gratian's Decretum. Referring to a passage from the first book of the Maccabees, he also recalls the ambassadors sent by Jonathan «to make peace» with Bacchide, while making it clear that both ambassadors and their senders must be suitably prudent, since no alliance should be established with wicked men $^{19}$.

\footnotetext{
${ }^{17}$ See Iulius Ferrettus, De Oratoribus, seu Legatis principum, \& de eorum fide, \& officio Tractatus, in: Id., Consilia et Tractatus, apud Ludovicum Avantium, Venetiis 1563, f. 81v-84v, which retains the structure of the first part of Lucas' commentary (twenty qualitates and twenty cautelae), while shortening the analysis. On this jurist and politician, born in Ravenna in 1487, died 1547, see P. Maffei, s.v. Ferretti, Giulio, in: Dizionario biografico dei giuristi itlaiani (XII-XX secolo), a c. di I. Birocchi, E. Cortese, A. Mattone e M.N. Miletti, Il Mulino, Bologna 2013, p. 848A-849A.

18 See C. de Benavente y Benavides, Advertencias para Reyes, Principes, y Embaxadores, por Fran. Martinez, Madrid 1643, cap. 8, p. 130 («[...] Della son hijas la verdad, la fidelidad, la prudencia, la fortaleza, i la templança, i las demas virtudes, que refiere Lucas de Penna»). On Benavente y Benavides, born in 1582, died 1645, after many years as a diplomat in the service of Philip IV, see Marques del Saltillo, Don Cristóbal Benavente de Benavides, conde de Fontanar, diplomático y tratadista (1582-1649), Escorial, 40 (1944), p. 319-346.

${ }^{19}$ See Lucas de Penna, Commentaria (supra, n. 14), p. 313A, $\mathrm{n}^{\text {os }}$ 9-10: «Legatorum quidem officium est inter eum ad quem, \& eum a quo mittuntur, amicitiam, societatem, pacemque firmare, 63 di. ego in fi. [c. $30 \S 1$, d. 63] \& 1 Machab. ca. 9. Misit Ionathas legatos componere pacem [1 Maccabees, 9.70], ut tamen
} 
Drawing on the classification of the munera civilia elaborated between the third and fourth centuries by the Roman jurist Arcadius Charisius, subsequently collected in the Digest, Lucas then observes that the «legatio» is a «munus publicum personale» - i.e. a personal obligation imposed on individuals which entails carrying out an activity without any implication of a financial obligation (unlike cases of munera patrimoniorum and munera mixta $)^{20}$. The compulsory nature of this munus, however, allows for exceptions. In the first place, an ambassador can be substituted by his son, according to a rule laid down in the Digest; extrapolating from a remark found in the gloss on the Decretum with regard to fasting, Lucas explains that no other relative can be accepted as a substitute $^{21}$. The Neapolitan jurist then goes on to give a list of justifications in his commentary on the first constitution collected in the title de legationibus, which ordains that the father of three healthy sons is exempt from embassy. First he mentions - as Accursius had already done - that the general rule for exemption from munera civilia was decreed for those with at least five sons, thus underlining the scope of this preferential rule which relieves ambassadors of the burdensome duty of traveling abroad and leaving children at home ${ }^{22}$. Then Lucas, again following the Magna Glossa, and after making a general reference to the reasons for exemption considered in the title de excusationibus munerum (Cod. 10.48(47)), adds other excusationes allowed in Roman law for nominees to the office of ambassador: the one set out a little further on, in the lex Transmarina (Cod. 10.65(63).3), which exempts legati who have returned from an overseas mission from all honores and munera civilia for two years; the one that benefits those who, having previously accused someone publicly, would be sent to one of his friends or relatives (a principle extended to benefit those who would be sent to an enemy

circa haec tam per mittentem quam per ipsum legatum opportunae circunspectionis sapientia procedatur, ut cum iniquis talia nunquam fiant, cum his namque non unio, sed dissensio \& separatio est tractanda».

${ }^{20}$ See ibidem, p. 320B, $\mathrm{n}^{\circ} 35$ : «Legationis etiam munus publicum est, quod quis subire compellitur. ff. de muner. \& honor. 1. fin. § legati [Dig. 50.4.18.12] \& not. s. de decurio. si quis decurio [Cod. 10.32(31).16]». For the classification by Arcadius Charisius, see. Dig. 50.4.18. On the system of munera, see F. Millar, Empire and City, Augustus to Julian: Obligations, Excuses and Status, The Journal of Roman Studies, 73 (1983), p. 76-96; and N. Lewis, The compulsory public services of Roman Egypt, Firenze 1997.

${ }^{21}$ See Lucas de Penna, Commentaria (supra, n. 14), p. 320B, $\mathrm{n}^{\text {os }} 35-36$ : «Nec ad hoc munus electi alios vicarios, quam filios dare possunt. ff. eod. titu. de leg. 1. sciendum. § legati [Dig. 50.7.5.4]. Sic non potest quis nisi per solum filium ieiunare. ut not. de poenit. distinct. 3 post. princ. in glos. ar. expressum \&c. [c. 4, C. 33, q. 3, d. 3] vel per aliam personam propinquam, ut not. 82 dist. presbyter. [c. 5, d. 82] quod tamen reprobatur in praedicta glos.». Indeed, the gloss puniens in se on c. 4, C. 33, q. 3, d. 3 says: «Arg. expressum quod quis non potest ieiunare per alium, licet contrarium diceret Hug. s. LXXXII di. presbyter [see gloss denarium on c. 5, d. 82]. Sed quicquid sit de alijs videtur quod per filium bene possit quis ieiunare: quia eadem persona censetur, ut xxxv q. iii $\S$ hac auctoritate [dictum post c. 21 , C. 35 , q. 2 et 3 ]. Et magis terrentur parentes in filijs quam in seipsis. ff. quod metus cau. 1. isti quidem $\S$ ult. [Dig. 4.2.8.3]» (Decretum Gratiani cum Glossis domini Johannis Theutonici [...], Basileae, [n.p.], 1512, f. 365vA).

${ }^{22}$ See Lucas de Penna, Commentaria (supra, n. 14), p. 321A, on Cod. 10.65(63).1: «Haec lex de se clara est. Dicit enim quod tre liberi excusant a legatione, in aliis muneribus requiruntur quinque, ut in glo. Et est ratio quare hic sufficiunt tres: quia gravantur peregrindando, \& filios relinquendo, ideo in hoc relevantur». See also Accursius, gloss pater trium on the same lex, in Corpus iuris civilis, 5 vol., Lyon, Hugues de la Porte, 1558-1560, vol. V, col. 86. The five-sons limit is established in Cod. 10.52(51).3.1. 
of theirs); and, lastly, the norm decreeing that no one is obliged to serve in an embassy if the person before him on the list drawn up by the assembly hasn't already done so $^{23}$.

Still on the subject of appointment, Lucas also examines the possibility, according to a common medieval custom, of sending several ambassadors on a mission ${ }^{24}$. He considers this to be, from one point of view, a good thing, given that the various members of the embassy can mutually support each other; however he also insists that all the envoys have to be well suited to the mission. In fact, as he writes, citing a decretal by Innocent III on the ordination of priests, it is better to appoint one capable ambassador than many incapable ones, since «if the blind lead the blind, both shall fall into the ditch». In any case, he notes the limit of three envoys given in the Digest, and explains that «the most prudent» among them will be chosen to speak. Whenever there is doubt as to who is actually the most prudent, the oldest will be chosen, but, again based on rules established for priests, «the oldest» should be chosen on grounds of wisdom rather than age, that is based on either his knowledge of law or his literary skill ${ }^{25}$. We will return to these aspects of the training of the ambassador later, when discussing his cultural qualities.

Lucas also discusses the letters of credence which an ambassador must possess. In the Middle Ages, as afterwards, in the early-modern age, these letters were the only essential documents for any official diplomatic envoy; they were proof of his status, they authorized him to speak on behalf of his principal and they entitled him to diplomatic immunities and prerogatives. The principle of the need for letters of credence was derived from canon, rather than Roman, law; more specifically, from the c. 3, d. 97. In his rubric, Gratian affirmed that, without a signed letter, the Roman Church would not receive any legation, whoever it came from ${ }^{26}$. Now, Nicholas I's letter, reproduced in the

\footnotetext{
${ }^{23}$ See Lucas de Penna, Commentaria (supra, n. 14), p. 321A, on Cod. 10.65.(63).1: «Pluribus etiam modis aliis quis a legatione excusatur, ut propter biennalem vacationem quam interim habet, ut patet in 1 . transmarina infra eo. titu [Cod. 10.65(63).3]. Item propter accusationem publicam quam de eo instituit, cuius se domesticum vel amicum dicit is ad quem mittitur. 1. sciendum $\S$ si accusatio. ff. eo. tit [Dig. 50.7.5(4).3]. Item propter ordinem non servatum d.1. sciendum $\S$ ordine [Dig. 50.7.5(4).5]. Item propter multas alias excusationes, quae ab aliis publicis muneribus excusant, de quibus supra de excusa. mune. per totum [Cod. 10.48(47)]». See also Accursius' gloss quoted in the previous footnote.

${ }^{24}$ See D.E. Queller, Early (supra, n. 7), p. 20.

${ }^{25}$ See Lucas de Penna, Commentaria (supra, n. 14), p. 317A, $\mathrm{n}^{\mathrm{0}} 28$ : «Tertio quia frequenter plures legati mittuntur, quod nimirum expedit: quia scriptum est, vae soli, quia cum ceciderit, non habet sublevantem. 7 q. 1 illud [c. 15, C. 7, q. 1], dum tamen omnes indonei sint. Nam alias sanctius est vel unum eligere bonum, quam plures malos destinare legatos: quia si caecus caecum ducat, ambo cadunt in foveam. extra de aeta. \& quali c. pen. [c. 14, $X$ 1.14] Quamvis ultra tres nulla civitas mittere debeat. ff. eo. tit. sciendum $\S$ ulti. [Dig. 50.7.5(4).6]. Ex eis prudentior eligatur: qui peroret. Matth. 22. Convenerunt in unum \& interrogavit eum unus ex eis legis doctor [Matthew, 22.34-35]. In dubio autem ad hoc est senior eligendus [...] vel qui ex eis magis abundat in scientia iuris, aut peritia litterarum. Hi namque vere sunt senes. 83 dist. c. porro. [but c. 6 , d. 84]».

${ }^{26}$ See c. 3, d. 97, rubrica: «Romana non consuevit ecclesia sine signatis apicibus legationem undecumque suscipere». For an overview of the forms and legal effects of the letters of credence in medieval diplomacy, see P. Chaplais, English diplomatic practice in the Middle Ages, London 2003, p. 12-16, 45-50, 102-103 and $175-191$.
} 
canon, while confirming this Church practice, informed the sender that his envoy had been welcomed in Rome even though he had no letters of credence, both out of respect for the sender and because of the gravitas of the envoy himself and the truth of his words ${ }^{27}$. Glossing this canon, Johannes Teutonicus had on the one hand reaffirmed the rule sanctioned by Gratian in his rubric and, on the other, accepted the exception, although limiting it to legates who were cardinals ${ }^{28}$. Having been endorsed by Henricus de Segusio and, with some reservations, by Guillaume Durand, this exception enjoyed a certain success in the literature on the ambassador ${ }^{29}$. Therefore, commenting on the lex Quotiens (Cod. 10.65(63).5) before discussing some of the formal aspects of letters of credence, such as seals and signatures, Lucas de Penna, in turn, mentions the cited canon, restating both the general rule and the exception, which he considers to be applicable not just to papal legates, but also to imperial envoys ${ }^{30}$.

On questions regarding the inviolability and privileges of the ambassador, Lucas begins by stating that, if the dignity of the sender requires it, ambassadors must be received with respect, since they are believed to embody their sender. Some of the norms invoked are of interest in this regard: for example, the canon Qui vos (c. 14, C. 8, q. 1), based on St Jerome's commentary on the Epistle to Titus, where the evangelical phrase «qui vos spernit, me spernit» - which Popes had been using for some time in the bulls with which they dispatched their legates - appears; the constitution of Theodosius II collected in Cod. 1.24.2, which requires that images and statues of the emperor be respected and is mentioned here in order to demonstrate the identification of the prince with his ambassador; and the canon Accusatio (c. 15, C. 7, q. 7), based on an Epistle from Pope Anacletus according to which any offence to a priest is an offence also to Christ, whose ambassadors the priests are («cuius legatione funguntur») ${ }^{31}$. It is on this last text that Lucas bases his unequivocal claim that any offence inflicted on an

\footnotetext{
${ }^{27}$ See c. 3, d. 97: «Nobilissimus vir atque strenuus vestrae sublimitatis legatus, licet nullam epistolam iuxta consuetudinem a vobis nostro Pontificio detulisset, licet numquam apostolicae sedis moris fuerit absque signatis apicibus undecumque legationem suscipere, nos tamen vos in illa honorantes, eiusque gravitatem et eloquiorum illius veridicas cognoscentes assertiones, nichilominus eum et sicut decuit suscepimus, et ei, sicut honestum fuit, credidimus».

${ }^{28}$ See in particular the gloss nihilominus: «Ergo et cardinali qui bene notus est in aliqua provincia credendum esset sine literis: maxime cum non contingat cardinalem unquam abesse nisi legationis causa» (Decretum (supra, n. 21), f. 101rB).

${ }^{29}$ See D. Fedele, Naissance (supra, n. 5), p. 205-207 for further references.

${ }^{30}$ See Lucas de Penna, Commentaria (supra, n. 14), on Cod. 10.65(63).5, p. 323B-324A, n ${ }^{\text {os }} 1-2$ : «Et nota quod debent legati \& ambassiatores habere decretum \& literas legationis. [...] \& est expressum 97 dist. nobilissimus [c. 3, d. 97] [...]. Et hoc verum in legato alterius quam Papae vel principis. Nam legatus eorum si alias hoc merentur virtutes eius absque legationis literis admittendus est dicto c. nobilissimus».

${ }^{31}$ See ibidem, p. 320B, ${ }^{\text {os }}$ 33-34: «Sciendum est autem quod per eos ad quos legati mittuntur, si mittentis hoc dignitas exigit, recipiendi sunt reverenter. supra de sum. tri. inter claras. ad fi. [Cod. 1.1(4).8.37]. Videtur quidem mittens ire per eos. 8 q. 1 qui vos [c. 14, C. 8, q. 1] supra de sta. \& ima. 1. 2 [Cod. 1.24(27).2] \& secunda quaestione septima. accusatio. [c. 15, C. 2, q. 7]». For some examples of the use of the evangelical formula «qui vos spernit, me spernit» in the papal bulls of Gregory VII, Paschal II and Innocent III, see D. Fedele, Naissance (supra, n. 5), p. 152.
} 
ambassador is inflicted upon that ambassador's sender, who is entitled to respond by declaring war on his offender: the example given is that of the war David waged on the Ammonites for the humiliation imposed by Hanun, the Ammonite king, on the former's ambassadors, who had arrived bearing his condolences on the death of Hanun's father. Moreover, Lucas also mentions here the three most important principles on the subject of the inviolability of the ambassador, one drawn from the Decretum and two from the Digest. In the first place, he refers to the canon Si quis autem (c. 2, d. 94) which records a passage from a letter by Alexander II stating that anyone who obstructs a papal legate will be punished with excommunication, on the grounds that in doing so they are hindering the work of God and causing trouble within the Church. Secondly, he cites the lex Si quis legatus (Dig. 57.7.18(17)), in which ambassadors are described as «sacred (sancti)» in ius gentium, meaning that no one can subject them to violence - even if war breaks out with the country from which they've been sent - for as long as their mission lasts; it states, moreover, that if they are attacked, the offender must be handed over to the ambassadors' principal so that the latter can take his revenge or, if he so decides, allow the offender his freedom. Lastly, through a reference to Guido da Baisio's Rosarium super Decreto, Lucas recalls the definition given in the lex Sanctum (Dig. 1.8.8), where Marcianus affirms that «sanctum» means «what is defended and protected from the injuries of men» and traces the etymology of the term back to sagmina, the sacred herb which the Roman legati carried as a mark of their position, so that no one would attack them ${ }^{32}$. Furthermore, ambassadors aren't just guaranteed inviolability: they also have to be accorded full honors and, Lucas emphasizes, must be listened to carefully, respectfully and silently, «just as one listens gravely to the word of the law» ${ }^{33}$.

The Neapolitan jurist gives us very little information about the salary to which the ambassador was entitled; in the $14^{\text {th }}$ century, however, the subject was discussed not

\footnotetext{
${ }^{32}$ See Lucas de Penna, Commentaria (supra, n. 14), p. 320B, $\mathrm{n}^{\circ}$ 34: «Unde contra eum qui legatos regis iniuriatur, iuste bellum indicitur. 2 Reg. c. 10.11 .12 [2 Samuel, 10-12]. His etiam qui legatum hostium quoque pulsaverit, tradendus est illis quorum legatus est hostibus puniendus. ff. eo. tit. 1. ultima [Dig. 50.7.18(17)]. Eis enim facta videtur iniuria, quorum legatione fungitur. 2 q. 7 accusatio in fi. [c. 15, C. 2, q. 7] \& facit 32. q. 7 offerebat in fi. [c. 12, C. 32, q. 7] \& 93 di. si quis [but c. 2, d. 94]. [...] Item sciendum est quod legati sunt sancti. ff. eod. titu. 1. fin. [Dig. 50.7.18(17)] quod qualiter accipiatur nota ibi \& per Archid. 96 distinct. cap. 1 alias 2 [but Guido da Baisio on c. 1, d. 97]». See also Guido da Baisio, Rosarium super Decreto, Venetiis, Andreas Torresanus, 1495, on c. 1, d. 97, unpaged. On this etymology, and on the nature, qualities and functions of sagmina, see G. Turelli, "Audi Iuppiter». Il collegio dei feziali nell'esperienza giuridica romana, Milano 2011, p. 70-76; on the concepts of «sanctio» and «sanctitas» in Rome, see Y. Thomas, De la «sanction» et de la «sainteté» des lois à Rome. Remarques sur l'institution juridique de l'inviolabilité (1983), in: Id., Les opérations du droit, éd. par M.-A. Hermitte et P. Napoli, Paris 2011, p. 85-102.

${ }^{33}$ See Lucas de Penna, Commentaria (supra, n. 14), p. 320B, n 34: «Ad hoc etiam 1 Macha 14. Susceperunt legatos Simonis gloriose [1 Maccabees, 14.40]. [...] Audiendi quoque sunt graviter \& diligenter 93 dist. c. diaconi sunt circa medium ibi [c. $23 \S 4$, d. 93], nec leviter hanc vocem qua loquitur, $\&$ pacem annunciat, audiant, aut negligenter accipiant, sicut nec lex negligenter audienda est. in authen. qui. mo. natu. effi. sui. § palam. in fi. § [Auth. 7.1, § Palam = Nov. 89.1]. [...] Nullus quippe strepitus aut tumultus, nec contumelia cum legati perorant agendi sunt, sed nec etiam risus est aliqualiter effundendus. 5 quaest. 4 in loco [c. 3, C. 5, q. 4]».
} 
only within the institutions of the Italian cities, where the intention was to keep the cost of diplomatic missions as low as possible, but also by ius commune jurists, more inclined to claim, at least, any damages incurred during a mission, given that the officium legationis was obligatory ${ }^{34}$. Following Accursius' Gloss, Lucas begins by saying that city statutes can allow for embassies to be paid for either out of the public purse or privately: in $14^{\text {th }}$ century diplomatic practice - it must be remembered - an embassy, far from always being the public office which jurists referred to, was often a private matter, carried out for personal interests, although with the backing of the ambassador's city, and in such cases it was considered that public money should not be used to fund the mission $^{35}$. Other than this, Lucas confines himself here to noting the privilege set down in a constitution by Arcadius and Honorius, in which foreign ambassadors to the emperor had the right to use the cursus publicus - i.e. horses maintained at the treasury's expense and kept at established stations along main routes in order to allow messengers to move at speed -, a privilege which no one else could enjoy without explicit authorization ${ }^{36}$.

Partly linked to the issue of salary is that of the gifts which an ambassador received at the end of his mission. There had been, for a long time, a question as to whether these goods should be considered to be the ambassadors' or their principal's property $^{37}$. Lucas does not address this question in his commentary on the title de legationibus, leaving it till later, in a long passage of his commentary on the title de castrensi peculio militum et praefectianorum (Cod. 12.36(37)); nevertheless, given the importance of this matter in the context of the legal debate on the ambassador's officium, it seems appropriate to mention it here. On this subject, the most authoritative opinion was that of Jacques de Revigny, who had formulated a solution beneficial to the ambassadors: an ambassador should be entitled to keep the gifts he had, unless these goods had been given to him with the express intention that they be delivered to his

\footnotetext{
${ }^{34}$ See D. Fedele, Naissance (supra, n. 5), p. 656-666 for further references.

${ }^{35}$ See Lucas de Penna, Commentaria (supra, n. 14), p. 320B, $n^{\circ} 36$ : «Posset etiam lex esse municipalis in civitate, ut suo sumptu quis ambasiatam facere teneatur, posset etiam quod publico. not. ff. de muner. \& honor. 1. honor. § 1»; and Accursius, gloss cum sumpto on Dig. 50.4.14.1, in Corpus iuris civilis (supra, $\mathrm{n}$. 22), vol. III, col. 1581. On contemporary Italian practice, see R. Fubini, Diplomazia e governo (supra, $\mathrm{n}$. 7), p. 26 and 46; S. Angelini, La diplomazia (supra, n. 7), p. 30-31; and D.E. Queller, Early (supra, n. 7), p. 13.

${ }^{36}$ See Lucas de Penna, Commentaria (supra, n. 14), p. 320B, $\mathrm{n}^{\text {os }}$ 36-37: «No. etiam quod praecipuum privilegium legatorum ad principem venientium esse, quod possunt uti cursu publico. j. de cur. pub. 1. his [Cod. 12.50(51).16], quo nullus alius uti potest absque literis principis [...]». On the meaning of «cursus publicus», see A. Alciatus, In tres posteriores Codicis Iustiniani Annotationes, Argentiane, Ioannes Schottus, 1515, on Cod. 12.50(51), f. 26r. Lucas ends this passage thus: «De aliis sumptibus legatorum exsolvendis, vide quod legitur \& not. extra de censi. cum instantia [c. 17, X3.39] \& s. de excusatio. muner. 1. maximarum § legatis [Cod. 10.48(47).12.3]» (Lucas de Penna, Commentaria (supra, n. 14), p. 320B, $\mathrm{n}^{\circ}$ 37).

${ }^{37}$ An early example of this debate appears in the quaestio $\mathrm{n}^{\circ} 131$ of the Collectio gratianopolitana, attributed to Placentinus, about a Milanese embassy to Byzantium that took place between 1167 and 1171: see A. Belloni, Le questioni civilistiche del secolo XII. Da Bulgaro a Pillio da Medicina e Azzone, Frankfurt am Main 1989, p. 18-19.
} 
principal. This opinion was argued both on the ground that ambassadors were free men, able to acquire property, and that it was the custom of the time for them to keep the gifts they received ${ }^{38}$. Lucas cites this opinion but, although in the end he arrives at a very similar solution, he begins by distancing himself from de Revigny's position. Basing his argument on the rule that the «exempla maiorum» are «pro lege servanda», he says that ambassadors must in any case hand the gifts over to their cities: as did the three Roman legati who, according to Valerius Maximus, on returning from their mission to the court of King Ptolemy, and even before having reported on their mission, gave the gifts they had received to the public treasury because they were convinced that no citizen should gain anything more from public office than the honor of having carried out his duty. As Valerius immediately makes clear, however, these gifts were returned to the ambassadors by a decree of the Senate and with the agreement of the people: and this, according to Lucas, was a decision inspired by a sense of fairness, since the ambassadors are required to sustain the onus legationis and often risk their very lives in the pursuit of their mission. Far from denying them their gifts, therefore, it is right that they should be entitled to keep them ${ }^{39}$.

One question remains, which brings us back to the commentary on the title de legationibus and towards a consideration of the behaviour of the ambassador: it regards his duty to respect his mandate scrupulously. The fundamental authority on the subject,

\footnotetext{
${ }^{38}$ See Petrus de Bellaperthica [but J. de Revigny], Lectura insignis et fecunda super prima parte Codicis, Parisiis, apud Galleotum du pre, 1519 [reprint Bologna 1967], on Cod. 6.2.22, f. 255rA-B, as well as Cynus Pistoriensis, In Codicem et aliquot titulos primi Pandectorum tomi, id est, Digesti veteris, doctissima Commentaria, Francofurti ad Moenum, impensis Sigismundi Feyerabendt, 1578 [reprint Roma 1998], on Cod. 6.2.22, f. 345vB, who recalls de Revigny's opinion.

${ }^{39}$ See Lucas de Penna, Commentaria (supra, n. 14), on Cod. 12.36(37).1, p. 855A-B, ${ }^{\text {os }} 8-10$ : «[...] Verum cum exempla maiorum sint pro lege servanda ff. de relig. minime. [Dig. 11.7.35] de poen. capitalium. § ult. [Dig. 48.19.28.16] \& plene scipsi s. de decur. exemplo [Cod. 10.32(31).36], videtur quod huiusmodi munera civitati sint omnino reddenda, ut enim refert Valerius lib. 4 c. de abstinentia [Valerius Maximus, Factorum et dictorum memorabilium, IV.3.9]. [...] Sed certe ut ibidem subditur, dona, quae praefati legati in aerarium deposuerant, decreto senatus, \& permissu populi eis restituta fuerunt, ita in iisdem Ptolemaei liberalitas, legatorum abstinentia, senatus, ac populi aequitas probabilis facti portionem obtinuit, \& ideo videtur aequius quod huiusmodi dona in dominium transeant legatorum. [...] Item legati coguntur onus legationis subire ff. de mune. \& hono. 1. fin. § legati [Dig. 50.4.18.12], \& propter legationem agendam interdum pericula saeva incurrunt, \& vitae renuntiare videntur. supra de princip. agen. in re. 1. principes [Cod. 12.21(22).6]. ad hoc etiam ff. pro socio. si non fuerit. ver. item si [Dig. 17.2.29.1], de dona. causa mor. 1.345 \& 6 [Dig. 39.6.1, 3-6]. \& ideo remunerandi sunt, non donis fraudandi. ff. de iur. immu. semper. § negotiatiores [Dig. 50.6.6.3]. Et si gravantur inviti, releventur ex hoc ut dona restituere non cogantur ff. de iureiur. eum qui. in princip. [Dig. 12.2.30.pr.] [...]». Lucas de Penna is known to have worked on a commentary on Valerius Maximus' Factorum et dictorum memorabilium during the 1370s, but this text was never published in its entirety. The three known manuscripts can be found at Auch, Bibliothèque municipale, ms. 8 (the only complete one), at Reims, Bibliothèque municipale, ms. 1332 (O. 884), and at Leiden, Library of the State University, Vossiani Lat. in Folio, 89 (I owe this information to E. Conte, s.v. Luca da Penne, (supra, n. 12)). The prooemium to the commentary has been published, on the basis of the Leiden manuscript, by M. Montorzi, Fides in rem publicam: ambiguità e tecniche del diritto comune, Napoli 1984, p. 355-365.
} 
the lex Diligenter (Dig. 17.1.5) ${ }^{40}$, is cited here to recall this duty, but Lucas does more than this. In fact, he borrows another tale from Valerius Maximus, that of the ambassadors who were sent to Tarentum by the Roman Senate in 281 B.C.: notwithstanding the serious injuries inflicted upon them by the Tarentines (one of the ambassadors even had his clothing urinated upon), they discharged their mission without complaining about what they had undergone, lest they say something that had not been included in their instructions. This episode, which was the cause of the Tarentine War, offers Lucas a concrete example of correct ambassadorial behaviour, where only the matters with which an ambassador has been charged are dealt with, and nothing is added on his own initiative . $^{41}$

\section{The qualities and conduct of the ambassador}

It has already been emphasized that the real novelty of Lucas de Penna's commentary on the title de legationibus of the Code is the fact that the author not only deals with the institutional and material aspects of embassies we have been examining, but for the first time also addresses a number of issues with regard to both the necessary qualities of an ambassador and the behaviour expected of him. In that sense, the commentary is not just an early attempt to assign a clear legal status to the ambassador (with the characteristics that we have examined above), but it also aimes to define what may be called the ambassador's "professional status". This status includes a number of objective qualities, required of anyone who wishes to assume the office of ambassador; some cultural qualities are also required, outlined in the form of a sort of curriculum; a list of moral virtues is proposed, considered essential by Lucas for the fulfilling of the function, which proves to be of crucial importance from the point of view of the moralization of the office; and, lastly, some words of caution are introduced, which are related to the need for diplomatic action to be effective and insist above all on the importance of the ambassador's use of words. Given the lack of precise references in Justinian's texts, these aspects are mainly discussed with reference to other sources,

\footnotetext{
${ }^{40}$ See Dig. 17.1.5: «Diligenter igitur fines mandati custodiendi sunt: nam qui excessit, aliud quid facere videtur et, si susceptum non impleverit, tenetur».

${ }^{41}$ See Lucas de Penna, Commentaria (supra, n. 14), p. 318A, $\mathrm{n}^{0}$ 28: «Septimo caveat ut a forma sibi iniuncti mandati non recedat. extra de rescrip. inter caetera [c. 4, $X$ 1.3]. sed mandatum ipsum debet in omnibus custodire. ff. man. diligenter [Dig. 17.1.5] \& 1. si quis pro e. [Dig. 17.1.46] \& integraliter s. mand. 1. cum mandati [Cod. 4.35.12]. ita quod fines eius non praetereat. Unde Valerius lib. 2 c. de institutis antiquis. Legati a senatu Tarentum ad res repetendas missi, cum gravissimas ibi iniurias accepissent, unus etiam urina respersus esset, in theatrum ut est consuetudo Graeciae introducti legationem quibus acceperant verbis peregerunt, de his quae passi erant questi non sunt, ne quid ultra ac mandatum esse loquerentur, intimisque pectoribus eorum antiqui moris respectus dolore, qui ex contumelia gravissimus sentitur, convelli non potuit [Valerius Maximus, Factorum et dictorum memorabilium, II.2.5]. Pura quoque \& simplex prout ei series negocij est commissa explicanda est, ne aliquid de suo adiiciens totam legationem partis mendacio decoloret. 3 q. 9 pura [c. 17, C. 3, q. 9]». For an assessment of this episode described by Valerius Maximus, see Ch.L.H. Barnes, Images and Insults. Ancient Historiography and the Outbreak of the Tarentine War, Stuttgart 2005.
} 
namely the classical texts (particularly Cicero on the figure of the orator) and the theological and canonical literature on the figures of the priest, the bishop and the novice.

All these elements seem to shed a new light on the officium of the ambassador, developing and enriching Lucas' analysis presented above. In fact, this elaboration reflected the historical evolution of the concept of officium from the Middle Ages onwards, an evolution which recent research has linked to the elaboration of a Christian and modern idea of the "profession" as an ethically valued activity carried out for the common good ${ }^{42}$. Most significant is the fact that, as it has been shown by some scholars, this evolution represented a condition of possibility for the establishment of the need, for office holders, to meet certain cultural and moral qualities: it played therefore a crucial role in the elaboration of a professional identity for public servants ${ }^{43}$.

Among the qualities listed by Lucas, four can be described as objective, i.e. unrelated to individual will. The first is that the ambassador be appreciated by his recipient, a quality that would appear essential if the ambassador is to be listened to favourably and the mission not compromised as soon as he opens his mouth. This is described here in a general way, in that Lucas does not specify what aspects are taken into account, only saying that the ambassador must «be loved» by the person to whom he has been sent and must, in turn, «love him». The numerous references included - taken from classical texts and from the Code, as well as from theological and canonical texts are generally intended to illustrate how important it is that the person acting as an intermediary does not fall into disfavour with his listener, thus risking the failure of the mission and further provoking the anger of those he wishes to reconcile ${ }^{44}$. The primacy of the theological and canonical sources is even more evident in the discussion of the second objective quality, the ambassador's age: a long list of texts is attached to this point too, many of which have nothing to do with the office of the ambassador, regarding instead the ordination of priests (like those taken from the distinctio 77 in the first part of the Decretum), or the offices of priest and bishop in general. Lucas uses these references

\footnotetext{
${ }^{42}$ For a more detailed discussion of this point, see T. Faitini, Il lavoro come professione. Una storia della professionalità tra etica e politica, Roma forthcoming, chap. 4.

43 See M. Santoro, «Professione»: origini e trasformazioni di un termine e di un'idea, in: Corpi, «fraternità», mestieri nella storia della società europea, a c. di D. Zardin, Roma 1998, p. 128. For an analysis of the elaboration of the professional status of the ambassador in the late medieval and earlymodern literature on this figure, see D. Fedele, Naissance (supra, n. 5), part II.

${ }^{44}$ See Lucas de Penna, Commentaria (supra, n. 14), p. 312A, $\mathrm{n}^{\circ} 3$ : «Legatus itaque talis eligendus est qui diligat eum ad quem mittitur, \& diligatur ab eo, ut not. de re iudi. ad apostolicae. lib. 6 [c. 2, VI 2.14, see the gloss salutem zelabantur], unde Cantic. 2 Dilectus meus loquitur mihi [Song of Songs, 2.10]. Naturale quippe est ut iudices eis quos libenter audiunt, facilius credant, dicit Quintil. lib. 4 de oratoria institutione [Quintilian, Institutio Oratoria, IV.1.12]. Eorum vero qui habentur odio, sicut prophanorum preces repelluntur, s. de offic. vic. 1. fi. in fi. [Cod. 1.38(42).2]. Nam qui non diligit facile contemnit, 20 q. 3 praesens. ultra medium [c. 4, C. 20, q. 3], \& facile contemnitur. [...] Cunctus quippe liquet, quia cum is qui displicet ad intercedendum mittitur, irati animus ad deteriora provocatur 3 q. 7 in gravibus [c. 5, C. 3, q. 7] 1 q. 1 fertur [c. 28, C. 1 , q. 1 ] \& 49 dist. c. 1 [dictum ante c. 1, d. 49]. Ab iratis itaque si perspicue pax \& benevolentia appetitur, non modo non invenitur, sed augetur potius, atque iflammatur odium, dicit Tullius in I rhetor. [Cicero, De inventione, I.21] [...]».
} 
to argue for his preference for a mature man, given the experience, self-control, wisdom and caution, which can be expected of him, without, however, necessarily excluding a young man whose virtue, maturity and moderation have already been demonstrated (like Daniel, to whom God gave «the honor of old age») $)^{45}$. Although these virtues are usually associated with older men, there is no reason why they should not also be found in comparative youth; but Lucas warns such young men to pay particular attention to the moderation of their speech. On the other hand, it must be remembered that a man weakened by old age cannot be expected to be fit for an office which inevitably demands considerable physical and moral strength. And so, immediately after discussing age, Lucas examines a third objective quality, requiring that an ambassador be robust and strong, both in body and soul, in order that he be able to do all that is necessary for the completion of the task with which he has been charged. In this regard, however, he refers not so much to the hardships and risks of the journeys which ambassadors must undertake, as to their ability to express themselves in resonant tones, in order to foster peace and friendship, as well as to the necessity, which sometimes arises, of addressing their interlocutors energetically ${ }^{46}$. The fourth quality that Lucas discusses is nobility: invoking the argument presented in another part of his Commentaria, he makes it clear

\footnotetext{
${ }^{45}$ See ibidem, p. 313B-314A, $\mathrm{n}^{\text {os }}$ 15-17: «Legatus debet esse aetate provectus. [...] Salust. in Iugurthino. Legantur in Aphricam maiores natu, seu aetate antiquus [Sallust, Bellum Iugurthinum, 25]: fide integer: in pressura probatus. 7 q. 1 . Novatianus [c. 6, C. 7, q. 1]. quem praecedens continentia dignum probet 77 dist. quicunque [c. 3, d. 77]. ne per aetatem (quod aliquotiens evenit) aliquo errore peccetur. ea. dis. episcopus [c. 6, d. 77]. Ante tempus quippe maturitatis, ante tempus examinationis, ante meritum obedientiae, ante obedientiam disciplinae, tales honores \& onera committenda non sunt 78 dist. quid est [c. 3, d. 78]. Solet enim in senibus esse morum maturitas. extra de renunc. 1 . nisi. $\S$ alia vero [c. $10 \S 3, X 1.9$ ] \& eo. tit. c. 1 [c. 1, $X$ 1.9]. ad hoc vide 84 dist. porro [c. 6, d. 84]. Scriptum est enim, In antiquis sapientia, $\&$ in multo tempore prudentia. Iob 22 [but $J o b, 12.12$ ]. [...] Verum si virtus eum extollat, non eo ipso quod est iuvenis est abiiciendus. unde Valer. lib. 3 c. 1, Iniquum est eum honori nondum tempestivum videri, qui iam virtuti maturus est [Valerius Maximus, Factorum et dictorum memorabilium, III.1]. Inde \& puer Daniel presbyteros iudicat. 2. q. 7 non omnes [c. 29, C. 2, q. 7]. Ei namque honor senectutis a domino datus est. Danielis 13 [Daniel, 13.50]. [...] Dum tamen huiusmodi iuvenes sint etiam morum honestate solliciti, ut in eis morum hoc doceatur habere probitas, quod prolixior consuetudo non contulit. 77 dis. monachus [c. 9, d. 77]. cuius etiam vitae, fideique integritas sit communiter approbata. ea. di. quicunque [c. 3, d. 77]. utque ipsos exactior ad bonos mores vita perducat. ea. di. in singulis [c. 2, d. 77]. ut etiam alia eis commissa officia laudabiliter ministraverint. eo. c. quicunque [c. 3, d. 77]. necnon ut clarae auctoritatis \& pollentis a mittentibus habeantur. ut dicit. Salu. ubi s. [Sallust, Bellum Iugurthinum, 25]. Talis ergo iuvenis cum legatus est, in perorando moderetur plurimum verba sua. ut Ecclesi. 32 [Sirach, 32.10-13]».

${ }^{46}$ See ibidem, f. 314A-B, no 18: «Legatus debet esse robustus, \& forti cordi seu animo, ut aptus sit omnem qui expediet perferre laborem. In eo etiam exigitur vox gloriosa s. de advo. diver. iudi. advocati. [Cod. 2.7.14]. Canit enim orator ut excitet ad pacem, laetitiam, iustitiam, \& virtutem animos audientium. Non ergo miserabiliter aut horride pronunciare debet, ut quosdam vel ad iram, vel ad luctum, lamentationemque compellat. [...] Est enim munus eius non ingenij solum, sed laterum \& virium omnino canorum id voce splendescit, ut ait Tullius li. de senectute [Cicero, De Senectute, 9.28] [...] Quare legatum oportet esse fortem robore».
} 
that he is speaking more about the nobility won through wisdom than that conferred by birth. With this clarification, the next group of qualities is introduced ${ }^{47}$.

Unlike the objective qualities, which are beyond the control of the individual, cultural qualities can be acquired by an ambassador through education. We know that at the end of the Middle Ages ambassadors (not ordinary messengers) were usually jurists or men of culture chosen from among a prince's entourage or the city's leaders: detailed knowledge of the law and of rhetoric were considered indispensable for an ambassador to reach agreements and to argue well and effectively ${ }^{48}$. This is exactly what Lucas de Penna says: he discusses the education of the ambassador in such great detail that these passages of his commentary can almost be read as an outline for an actual training programme. Already in his very first pages, the Neapolitan jurist says that the «virtus [...] oratoria seu eloquentiae, \& facundiae» is a chief attribute of the ambassador; he adds that it is appropriate to elect jurists to this office, choosing particularly those who are most eloquent, a quality that can best be acquired through a deep understanding of the Holy Scriptures ${ }^{49}$. Lucas, nevertheless, here appears to draw more on Cicero than on the Bible, first defining rhetoric as part of «civil science» and then quoting some passages from the first book of the De oratore. Like Cicero, he insists that the ambassador must possess the acuteness of the logicians, the thought of the philosophers, the words of wise men, the memory of the poets, the voice of the lawyers and the bearing of the tragedians. Lucas exhorts him to leave his domestic and retired exercise of oratory and go out, «right into action, into the dust and uproar, into the camp and the front-line of public debate» in order to test the strength of his talent. The ambassador must also read the poets, acquaint himself with history, «study and peruse the masters and authors in every excellent art, and by way of practice praise, expound, emend, criticize and confute them»; he must «argue every question on both sides, and bring out on every topic whatever points can be

\footnotetext{
47 See ibidem, p. 314B-315A, $\mathrm{n}^{\circ}$ 20: «Eligendus est legatus nobilis. Salust. in Iugurthino. Legantur in Aphricam maiores natu nobiles amplis usi honoribus, \& statim ille ubi accepit homines claros, quorum auctoritatem Romae pollere audiverat contre inceptum suum venisse \&c. [Sallust, Bellum Iugurthinum, 25]. Ea siquidem nobilitate praesignis qua perfectae legationis ministerium exequatur, puta sapientia quae omnibus nobilibus nobilior est. Sapientiae 7 [Wisdom, 7]. [...] Non ea quae a progenitoribus parta per successores elationis se vitio erigentes damnose pariter \& ignominiose corrumpitur. [...] De hac materia plene scipsi d.1. mulieres [Cod. 12.1.13] s. de condit. in pub. hor. 1. 1 [Cod. 10.26.1]».

${ }^{48}$ On the development of the ars concionandi from the $13^{\text {th }}$ century onwards and on the eloquence of Italian ambassadors, see E. Artifoni, I podestà professionali e la fondazione retorica della politica comunale, Quaderni storici, 63 (1986), p. 697-719, and Id., L'éloquence politique dans les cités communales (XIII siècle), in: Cultures italiennes (XII ${ }^{\mathrm{e}}-\mathrm{XV}^{\mathrm{e}}$ siècle), éd. par I. Heullant-Donat, Paris 2000, p. 269-296. The importance of sending eloquent ambassadors is emphasized in about 1234 by I. Viterbiensis, Liber de regimine civitatum, prodit curante Caietano Salvemini, [Bibliotheca Iuridica Medii Aevi, 3], Bononiae, in aedibus Successorum Monti, 1901, cap. 123, p. 50A. On the employment of jurists, see D. Queller, The Office (supra, n. 4), p. 156-157.

${ }^{49}$ See Lucas de Penna, Commentaria (supra, n. 14), p. 311B, introduction and $n^{\circ} 1$ : «Virtus autem oratoria seu eloquentiae, \& facundiae potissimum est attributa legatis. [...] Ad huiusmodi legationis officium praecipue iurisperiti sunt assumendi, \& consueverunt assumi qui maxime facundia polleant [...] \& qui sint imbuti scriptura divina, a qua omnis splendor rhetoricae eloquentiae, omnes modi poeticae locutionis, quaelibet varietas decore pronunciationis sumpsit exordium. 37. dist. § hinc etiam [c. 7, d. 37]».
} 
deemed plausible»; besides this, he must «become learned in the civil law and familiar with the statutes», as well as «contemplate all the olden time, and investigate the ways of the senate, political philosophy, the rights of allies, the treaties and conventions»; and, lastly, «cull, from all forms of pleasantry, a certain charm of humour, with which to give a sprinkle of salt, as it were», to all of his discourse ${ }^{50}$.

This direct transfer of Cicero's precepts regarding the orator demonstrates Lucas' predominant interest in the need for an ambassador to be a deeply cultured man, rather than superficially eloquent. As he says further on, quoting another passage from the De oratore, «no man can be an orator complete in all points of merit, who has not attained a knowledge of all important subjects and arts. For it is from knowledge that oratory must derive its beauty and fullness, and unless there is such knowledge, wellgrasped and comprehended by the speaker, there must be something empty and almost childish in the utterance ${ }^{51}$. In other words, eloquence is useless if the speaker is not wise; in fact it may be very damaging. And this «wisdom», as Lucas explains, consists mainly of knowledge of philosophy and the divine law ${ }^{52}$.

\footnotetext{
${ }^{50}$ See ibidem, p. 311B-312A, $\mathrm{n}^{\text {os }}$ 1-3: «Ipsa quoque rethorica pars est civilis scientiae, dicit Tullius I. rhetoricorum [Cicero, De inventione, I.6] [...] In oratore autem acumen dialecticorum, sententia philosophorum, verba prudentium, poetarum memoria, iurisconsultorum vox, tragoedorum gestum pene summo citatiorem non sane mihi displicet adhibere [see Cicero, De oratore, I.28.128, slightly different]. Educenda deinde dictio est ex hac domestica exercitatione, \& umbratili medium in agmen, \& in pulverem, in clamorem, in castra, atque in aciem forensem: subeundus usus omnium, \& periclitandae vires ingenij. Et illa commentatio inclusa in veritatis lucem proferenda est. Legendi etiam poetae, cognoscendae historiae, omnium bonarum artium doctores, atque scriptores legendi \& pervolutandi, \& exercitationis causa laudandi, \& interpretandi, corrigendi, vituperandi, disputandumque de omni re in contrarias partes. Et quicquid erit in quaque re quod probabile videri possit, eligendum, atque discendum, \& perdiscendum ius civile, cognoscendae leges, percipienda omnis antiquitas senatoria consuetudo disciplina rei publicae iura, sociorum foedera cognoscenda. Est libandus ex omni genere urbanitatis facetiarum quidam lepos, quo tanquam sale perspergatur omnis oratio, ut ait Tullius lib. I de oratore [Cicero, De Oratore, I.34.157-159]». I have used E.W. Sutton's translation of Cicero's De Oratore, with an introduction by H. Rackham, Cambridge Mass. 1967, vol. I, p. 107-109.
}

${ }^{51}$ See ibidem, p. 316A, $\mathrm{n}^{0}$ 26: «\& Tullius lib. I de oratore. Mea quidem sententia nemo poterit esse omni laude cumulatus orator, nisi erit omnium rerum magnarum atque artium scientiam consecutus, \& ex rerum cognitione florescat, \& redunder oportet. Oratio quae nisi sit ab oratore percepta, \& cognita, inanem quandam habet elocutionem, \& pene puerilem [Cicero, De oratore, I.6.20]» (and, for the translation, Cicero, De Oratore (supra, n. 50), vol. I, p. 17).

${ }^{52}$ See ibidem, p. 312A-312B, n ${ }^{\text {os }}$ 5-7: «Attendendum est quod non solum sit orator eloquens, sed etiam sit sapiens, 84 dist. porro [c. 6, d. 84], tunc enim ex eloquentia vita iucunda, honesta illustrisque est, tunc ex ea reipublicae plura commoda veniunt, quando moderatrix omnium rerum praesto est sapientia, dicit Tullius in prologo suae retho. [Cicero, De inventione, I.5]. Eloquentia vero sine sapientia nimium obest civitatibus plerunque, nunquam autem prodest, quamvis sapientia sine eloquentia parum prosit, ibidem [voir ibidem, I.1] [...] Quare in legato nimium exigitur sapientia ne dicatur adversus eum cum orat, Quis est hic involuens sententias suas sermonibus imperitis ? Iob. 35 [Job, 38.2]. Sapiens enim in verbis suis se amabilem facit [Sirach, 20.13]. \& infra. Sapiens in verbis suis producit seipsum [Sirach, 20.29]. [...] \& Boetius 2 de consola. Absit rhetoricae suadela dulcedinis, quae tunc tantum recto calle procedit quando nostrae, id est, philosophiae instituta non deserit [Boethius, De consolatione philosophiae, II.1]. Ex sapientia quoque his qui eam adepti sunt, laus, honor, dignitas confluit. hinc amicis quoque ipsorum certissimum \& tutissimum refugium comparatur. dicit Tullius in eodem prologo [Cicero, De inventione, 
The Neapolitan jurist then draws our attention to one aspect in particular, again demonstrating the originality and richness of his thought - an ambassador's knowledge of foreign languages. Here, too, he bases his argument on a rule for bishops, to whom the Fourth Lateran Council granted permission to nominate auxiliaries, or even a vicar, to the dioceses where the faithful spoke different languages, in order to address the problem, which became urgent after the expansion of the Roman Church into the Orient after the Crusades, of the coexistence in the same diocese of communities with different languages and rites. This is a very short passage in Lucas' discourse, but it is of great importance: although he does not mention interpreters and the problems of accuracy and loyalty raised by their use, Lucas explains that if an ambassador can speak foreign languages he can carry out his duties «by himself» ${ }^{53}$. He thus demonstrates a clear understanding of the communication problems which contemporary diplomats were already experiencing: despite the widespread use of Latin, addressing a foreign ruler in a language not his own could have been considered inappropriate ${ }^{54}$.

As well as the objective and cultural qualities, Lucas de Penna examines a series of virtues which he considers necessary to moralize the office of the ambassador, within the framework of a discourse which acquires a strong paraenetic connotation. Lucas first considers loyalty, and in doing so he develops some images taken from the book of Proverbs. He says that a trusty messenger «brings healing» and revives the soul of his master like «the coolness of snow in harvest time», while, in contrast, a disloyal ambassador is not only a plague on the land to which he has been sent, and through which he travels, since his bad example might corrupt many others: he is even like a «decaying tooth», causing great pain, or a «lame foot», stopping its possessor from walking, and, for these reasons, he must suffer the poena capitis ${ }^{55}$. Some words are then

I.5]. Adeo quoque legati debent esse pleni sapientia, quod sint etiam pleni sermonibus. [...] Non enim sufficit legatum solum eloquentem esse [...] Non ergo debet esse legatus ignorans [...]. Quinimmo sit in legato legis claritas \& scientiae 8 q. 1 si ergo in fin. [c. 16, C. 8, q. 1] nihilque sapientiae, nihilque scientiae, nihil in eo desit industriae ea. q. licet. [c. 15, C. 8, q. 1]». Lucas returns to the eloquence of the ambassador ibidem, p. 314B, $\mathrm{n}^{\circ} 19$, and f. 316A, $\mathrm{n}^{\circ} 26$.

${ }^{53}$ See ibidem, p. $316 \mathrm{~A}, \mathrm{n}^{0}$ 24: «Plurium quoque linguarum sit peritus si fieri potest, qui secundum diversitatem rituum, \& linguarum officium legationis impleat per seipsum. extra de offi. or. quoniam [c. $14, X 1.31] »$. On this canon, see O. Condorelli, «Unum corpus, diversa capita»: modelli di organizzazione e cura pastorale per una varietas ecclesiarum (secoli XI-XV), Roma 2002, p. 22-45.

${ }^{54}$ Consider the case of Petrarch who, sent by Galeazzo Visconti II to the court of John II of France in 1361, apologized during his first audience for speaking in Latin, explaining that he could not speak the «lingu[a] gallic[a]»: see T. Haye, Die lateinische Sprache als Medium mündlicher Diplomatie, in: Gesandtschaftsund Botenwesen im spätermittelalterlichen Europa, hrsg. von R.C. Schwinges und K. Wriedt, Ostfildern 2003, p. 20-21, giving an extract from Petrarch's speech.

${ }^{55}$ See Lucas de Penna, Commentaria (supra, n. 14), p. 312A, $\mathrm{n}^{\circ}$ 4: «Eligendus est legatus fidelis; seu fide integer. 7 q. 1 Novacianus [c. 6, C. 7, q. 1]. Nam legatus fidelis sanitas. Prover. 13 [Proverbs, 13.17]. Sicut enim frigus nivis in die messis, ita legatus fidelis ei qui misit illum. Proverb. 25 [Proverbs, 25.13]. unde \& Salust. in Iugurthino. Rex Bochus scilicet ex omni copia rerum quinque delegit quorum fides cognita, \& ingenia validissima erant [Sallust, Bellum Iugurthinum, 103]. Econtrario legatus infidelis pestilentia est terrae ad quam, seu per quam mittitur. Pravo quidem exemplo multos corrumpit. Prover. 25. Dens putridus, $\&$ pes lassus qui sperat super infideli in die angustiae [Proverbs, 25.19]. Dens enim putridus ori gravem 
given to the virtue of justice, with the warning that no unjust man should be appointed to this office ${ }^{56}$, and a great emphasis is placed on an exhortation to the ambassador to be truthful and to avoid the use of flattery when addressing the recipient of his mission ${ }^{57}$. Similar attention is then paid to temperance; Lucas warns the ambassadors above all against the terrible consequences of drunkenness which «blinds the conscience and buries reason» ${ }^{58}$. Moderation and modesty are also praised, especially in speech, although the ambassador should not be expected to forego a certain freedom and even audacity when addressing his interlocutor ${ }^{59}$. Finally, Lucas urges that an ambassador

dolorem ingerit. Unde vulgariter dicitur. Non est dolor sicut dolor dentis. Igitur infidelis nuncius est ei qui sperat in illo, ut dens putridus qui est ei occasio magni doloris. Est etiam ut pes lassus, sicut enim multum affligitur, qui desiderat pervenire ad locum aliquem, \& prae lassitudine impeditur, sic affligitur qui expectat nuncium infidelem qui moram nimiam facit. Et ideo his similes, poena capitis puniuntur. j. de navicul. 1. pen. [Cod. 11.2(1).5] [...]».

${ }^{56}$ See ibidem, p. $312 \mathrm{~B}, \mathrm{n}^{\circ}$ 8: «Quarto ut sit iustus. In semita namque iustitiae vita. Iter autem devium ducit in mortem. Proverb. 12 [Proverbs, 12.27]. Non enim alius quam iustus homo idoneus corrector est. psal. 32 Corripiet me iustus [Psalms, 141(140).5]. [...] Iniqui ergo non sunt ad legationis officium eligendi. Nam \& $\mathrm{ab}$ his ad quos diriguntur potius repellentur».

${ }^{57}$ See ibidem, p. 313A, $n^{\circ}$ 9: «Signanter attendendum est ut [legatus] sit verax. Exodi 18. Provide ex omni plebe viros potentes, \& timentes Deum, in quibus sit veritas, \& qui oderint avaritiam [Exod, 18.21]. Prover. 8. Veritatem meditabitur guttur meum [Proverbs, 8.7] \& subdit. Testis falsus non erit impunitus, \& qui mendacia loquitur, non effugiet [ibidem, 19.5] \& infra, qui loquitur mendacia peribit [ibidem, 19.9] [...] Super his non adiicio plura : quia veritas hodie ab omnibus fere effugatur. [...] Itaque legatus in explicanda legatione sua nulla adulatione demulceat veritate suppressa. Prover. 8. Aperiuntur labia mea ut recta praedicem [Proverbs 8.6], vitet adulationem, utque non sit assentator, neque palpo [...]. Plus enim nocet lingua adulatorum quam manus interfectorum. dicit. August. super Psal. 69 [Augustine, Enarratio in Psalmum LXIX, $\mathrm{n}^{\circ}$ 5, in: Id, Esposizioni sui Salmi, a c. di V. Tarulli, t. II, Roma 1970, p. 706]. [...]».

${ }^{58}$ See ibidem, p. 313B, $\mathrm{n}^{\mathrm{0}}$ 12: «Legatus debet esse sobrius. 35 di. vinolentum [c. 6, d. 35]. Non ebriosus. Nam ubi est ebrietas ibi luxuria \& furor dominatur. ea. di. luxuriosa [c. 3, d. 35]. Obcaecat enim conscientiam : \& sepelit rationem. 15 q. 1 sane [c. 2, C 15, q. 1]. Unde Aristo. ad Alexandrum. Nec mittas nuncium tuum qui diligat vinum, \& se inebriet : quia Perses in adventu nuncij instabant apud ipsum ut biberet vinum abundanter [see Secretum Secretorum cum glossis et notulis, nunc primum edidit Robert Steele, Oxonii, E typographeo Clarendoniano, 1920, pars 3, cap. 16, p. 148]». Other quotations follow, from Galen, Cicero and Saint Jerome, intended to illustrate the advantages of «sobrietas» and the disadvantages of «ebrietas». See on this question B. d'Alteroche, Observations sur la prise en compte de l'ébriété par le droit canonique classique, in: Mélanges en l'honneur d'Anne Lefebvre-Teillard, études coordonnées et rassemblées par B. d'Alteroche et al., Paris 2009, p. 33-52.

${ }^{59}$ See Lucas de Penna, Commentaria (supra, n. 14), p. 315B, $\mathrm{n}^{\mathrm{o}} 23$ («Debet esse moderatus, ut in omnibus modestiam servet, maxime ut non arroganter in sua legatione procedat, sed modeste verbo agat, disputatione pugnet, ratione vincat. 23 q. 6 vide [c. 3, C. 23, q. 6]»); and p. 318A, n ${ }^{\text {os }} 28-30$ («Postquam perorare inceperit, ante quoque attentissime caveat, ut non timide loquatur, sed libere. Debent enim oratores audaces esse, \& prae caeteris libera voce loqui sicut clerici. no. in authen. de non alie. $\S$ oeconomum [Auth. $2.1 \S$ oeconomum $=$ Nov. 7, Praefatio]. [...] Et ideo iustissime timidi legati vocantur canes muti, non valentes latrare. 43. dist. sit rector [c. 1, d. 43]. Docet quippe negare qui timide rogat, dicit Senec. in Hippolyto [Seneca, Phedra, v. 593-594] [...]»). 
should be chosen who is prompt and willing in the undertaking of his mission, so that he will act zealously and diligently in fulfilling the task with which he has been entrusted ${ }^{60}$.

Nevertheless, we must emphasize that, for Lucas de Penna, the ambassador's actual behavior is as important, if not more, than the, rather more theoretical, list of requisite virtues. Thus, echoing almost exactly the virtues attributed to the former high priest Onias in the second book of the Maccabees, Lucas asks that the ambassador be a kind and good man, pleasant of bearing, gentle of manners, suitably eloquent and trained from childhood in the practice of every virtue ${ }^{61}$. The detail into which Lucas goes on the subject of the gestures and gait of the ambassador appears particularly significant to us from this perspective, since - according to the Augustinian principle of the incompositio corporis, neatly transferred from the «cleric $[i]$ professi $[o] »$ to the «legationis officium»a man's outward bearing was believed to manifest his inner qualities ${ }^{62}$. Lucas emphasises this point, even adapting to the ambassador a passage from the De institutione novitiorum in which Hugh of Saint Victor lists some inappropriate physical behaviours and associates each of them with a defect of the soul, in order to urge novices to moderate their outward behaviour ${ }^{63}$.

\footnotetext{
${ }^{60}$ See ibidem, p. $315 \mathrm{~A}, \mathrm{n}^{\mathrm{o}} 21$ : «Legatus debet esse sollicitus \& solers. 84 dist. c. $1 \& 2$ non negligens [c. 1 and 2, d. 84]. Nam sicut in unoquoque opere mater est instantia, ita noverca eruditionis est negligentia. 83 dist. nihil [c. 6, d. 83]. [...]. Nam sicut acetum dentibus, \& fumus oculis: sic piger his qui miserunt eum. dicitur Proverb. 10 [Proverbs, 10.26] \& Salust. in Iugurthi. Duos maxime impigros elegit: quorum ingenia validissima erant [Sallust, Bellum Iugurthinum, 23 and 103]».
}

${ }^{61}$ See, ibidem, p. 316A, $\mathrm{n}^{\circ}$ 26: «Legatus sit vir bonus \& beningus, iucundus visu, modestus moribus, \& eloquio decorus, \& a pueritia virtutibus exercitatus 2. Macha. c. penul. [2 Maccabees, 15.12]. Qui se maturum atque efficacem valeat in omnibus exhibere. 7 q. 1 quamvis. in fi. [c. 14, C. 7, q. 1]. Doctior, eminentior. 8 q. 1 licet [c. 15, C. 8, q. 1]».

${ }^{62}$ See ibidem, p. 315A, $\mathrm{n}^{\circ} 22$ : «Habitu \& incessu debet esse maturus, ut in his quoque probet debitum suae legationis officium. 41 dist. clericus [c. 8, d. 41]. Compositio enim \& incompositio corporis qualitatem mentis ostendit, secundum Aug. e. dis. in fi. ubi etiam alegatur illud Salust. in Catilinar. Incessus eius modo citus, modo tardus». The c. 8 , d. 41, which records a canon from the Fourth Council of Carthage, states that «clericus professionem suam et habitu et incessu probet, et ideo nec vestibus, nec calceamentis decorem quaerat». Gratian adds a dictum in which he says: «[...] In incessu autem debet esse sacerdos ornatus, ut gravitate itineris mentis maturitatem ostendat. Incompositio enim corporis (ut Augustinus ait) inaequalitatem indicat mentis [maybe Augustine, De Regula, in: Id., Morale e ascetismo cristiano, Roma 2001, cap. 4, p. 36]. Unde historiographus ille [...] dicens: Citus modo, et modo tardus incessus [Sallust, Bellum Catilinae, 15]».

${ }^{63}$ See ibidem, p. 315A, n ${ }^{\circ} 22$ : «Gestus autem membrorum in hoc attenditur, ut praecipue quinque devitet. Primo videlicet ne sit mollis, nec dissolutus, procax, aut tardus, citus, aut turbidus. Mollis enim gestus lasciviam significat. Dissolutus negligentiam. Citus inconstantiam. Procax superbiam. Turbidus iracundiam»: as can be seen, Lucas mentions five negative attitudes, then lists six, finally explains five of them again, in a passage modelled on De institutione novitiorum, but which doesn't reproduce the words «tardus pigritiam» (see Hugh of Saint Victor, De institutione novitiorum, in: Id., L'œuvre de Hugues de Saint-Victor, t. 1, Turnhout 1997, cap. 12, p. 58). Lucas adds ibidem: «Est autem facies speculum orationis, cui tanto maior custodia adhibenda est, quanto minus, si quid in ea peccatum fuerit, celari potest. Temperanda est igitur facies gestu suo, ita ut nec protere exasperetur, nec mollis dissolvatur, sed semper habeat \& rigidam dulcedinem, \& dulcem rigorem» (see Hugh of Saint Victor, De institutione novitiorum (supra, n. 63), p. 70, where, however, Hugh writes «disciplinae» instead of «orationis»). Drawing again on Hugh of Saint Victor (according to whom «est enim quasi quaedam respublica corpus humanum, in quo 
And finally we come to a series of words of caution which Lucas presents in his commentary, intended not so much to guarantee the morality of the ambassador as the efficacy of his actions. They are collected in a discussion of a particular intellectual virtue - «discretion», a form of pragmatic judgment which considers each case on its own merits ${ }^{64}$ - and deal mainly with the ambassador's use of words. Given the considerable space which Lucas devotes to this question, one could consider it to be an elaboration, albeit somewhat rhapsodical, of an actual speaking technique which he proposes for ambassadors, again «following the example of the priests». It is in fact «sacerdotum exemplo» that the ambassador must be not only «learned» but also «discreet in all matters»: he must be able to read situations and interlocutors accurately in order to adapt himself most appropriately to them, given that the differences between people, as the Decretum says, requires that each person should be given a different medicine ${ }^{65}$. This is why Lucas accords particular importance to the evaluation of the quality of things, of people and of times: the «tempus aptum» and the «opportunitas» are shown to be essential criteria for successful speeches ${ }^{66}$. He returns to this point a number of times, on the one hand drawing copiously from the Decretum and, on the other, quoting the De oratore, according to which no single kind of style can be adapted to every cause, or every audience, or every person, or every occasion - the style must vary according to the people and circumstances involved ${ }^{67}$. Above all, an ambassador's discretion entails his

singulis membris officia sua distributa sunt», Hugh of Saint Victor, De institutione novitiorum (supra, $\mathrm{n}$. 63), p. 72) and on c. 1, d. 89 (which says that «indecorum est, ut in corpore humano alterius fungatur officio alterum membrum»), Lucas then exhorts the ambassador to moderate his gesta, so that «non [...] permutentur officia membrorum, neque inordinate permisceantur». He then writes: «Gestus igitur legati debet esse gratiosus sine mollicie, quietus sine dissolutione, gravis sine tarditate, alacer sine inquietudine, maturus sine protervia, severus sine turbulentia. ut haec $\&$ alia in similibus bene prosequitur Hugo lib. de institutione novitiorum [see Hugh of Saint Victor, De institutione novitiorum, (supra, n. 63), p. 74, who speaks of «gestus homini», not of «gestus legati»]. Ut etiam habitus legationi congruat» (ibidem, p. 315B). Finally, Lucas refers again to c. 8, d. 41 (see supra, n. 62), as well as to C. 21 , q. 4 per totum and to Valerius Maximus, Factorum et dictorum memorabilium, VIII.10.

${ }^{64}$ See Fr. Dingjan, Discretio. Les origines patristiques et monastiques de la doctrine sur la prudence chez saint Thomas d'Aquin, Assen 1967.

${ }^{65}$ See Lucas de Penna, Commentaria (supra, n. 14), p. 313A-313B, $\mathrm{n}^{\circ}$ 11: «Legatus debet esse discretus in omnibus \& doctus, sacerdotum exemplo. 38 di. per totum [d. 38 per totum] ut arguat, increpet, obsecret in omni patientia \& doctrina 2 ad Timoth. c. 4 [2 Timothy, 4.2] \& 45 di. c. 1 \& per totum [c. 1, d. 45 and d. 45 per totum]. Quosdam quippe clam: quosdam vero palam, sicut diversitas personarum diversam potest accipere medicinam. 14 q. 6 c. 1 in fi. [c. $1, \S 4$, C. 14, q. 6]. Consilium namque pro cuiusque moribus capiendum est, quosdam enim preces vincunt».

${ }^{66}$ See ibidem, p. $317 \mathrm{~B}, \mathrm{n}^{\circ}$ 26: «Quarto ut is qui peroraturus est in explicando sermone observet loca, \& tempora, \& personas, ut opportuno loco, opportuno tempore, \& praesentibus quibus convenit, quae sunt iniuncta loquatur. 22 q. 5. quotiens [c. 21, C. 22, q. 5] 2. ad Timo. c. 5 [2 Timothy, 4.2]. \& Terentius in Adel. In tempore, scilicet, opportuno ad eam veni, quod, scilicet, opportunitas rerum omnium est primum [Terence, Heauton Timorumenos, v. 364-365]. [...] Omni quoque negocio tempus est \& opportunitas Ecclesia. 8 [Ecclesiastes, 8.16] \& sermo opportunus optimus est. Prover. 15 [Proverbs, 15.23]».

${ }^{67}$ See ibidem, p. 319A, $\mathrm{n}^{\circ}$ 32: «Ut iuxta qualitate eorum quos alloquitur pensate verba diffundat, \& pro ingenio audientium se adaptet : verborumque ordinem pro audientium capacitate dirigat. 8 q. 1. oportet. [c. 
ability to be silent, since, according to Gregory the Great, «he who knows how to remain silent when appropriate, knows how to talk opportunely», while, in contrast, according to Ecclesiastes, «a fool multiplies words» ${ }^{68}$. The ambassador should therefore be «utilis in verbo, discretus in silentio», in order not to «reveal that which he should not speak of or be silent about that which he should reveal»: he should «weigh his words on the scales of his caution, so that everything he says is honed before it arrives on his tongue» ${ }^{69}$. Finally, still on the subject of effective discourse in different situations, Lucas formulates some precepts in relation to the modulation of tones of voice and the need to develop a certain ability to vary one's facial expressions: a skill which, in his opinion, the ambassador should acquire by practising in front of a mirror ${ }^{70}$.

\section{Conclusion}

Lucas de Penna's commentary on the title de legationibus undoubtedly deserves a more detailed analysis. One may even suggest a critical edition which would provide easy access to all the sources used by the Neapolitan jurist. The aim of the present

12, C. 8, q. 1] iuxta doctrinam apostoli. Factus sum infirmus infirmis 45 dist. c. recedite [c. 16, d. 45]. utque non det sanctum canibus, neque mararitas mittat ante porcos, ne forte conculcent eas pedibus, \& conversi disrumpant eum. undecima quaestione tertia. nolite [c. 22, C. 11, q. 3] \& 43 dist. in mandatis [c. 2, d. 43]. [...] Sed si rei qualitas \& personae audientium exigunt, nunc exordiatur, nunc insinuet, modo arguat, narret, rationes afferat, exempla producat. [...] Quinetiam illud perspicue debet attendere quod non omni causae nec auditorum personae, neque tempori unum genus congruit orationis. [...] Et licet ornare, illustrareque orationem sit artis \& naturae, scire tamen quando quique deceat prudentiae solius est, ut ait Tullius 2. de oratore [but Cicero, De oratore, III.55.210]».

${ }^{68}$ See ibidem, p. 317, $n^{\circ}$ 26: «Unde Gregorius [...] li. 30 moralium. Ille scit recte dicere, qui novit ordinate tacere [Gregorius Magnus, Moralia in Iob, Turnhout 1985, lib. 30, cap. 8, $\mathrm{n}^{\circ}$ 27, p. 1509]. [...] Quinto ut silentium attendat». See also ibidem, p. 318B, $\mathrm{n}^{\circ}$ 30: «Nam in multis sermonibus invenitur stultitia. dicit Salo. eccle. 5 [Ecclesiastes 5.2] \& c. 10. Stultus verba multiplicat [ibidem, 10.14] [...]. In hoc tamen attendat rerum, personarum \& temporum qualitates».

${ }^{69}$ See ibidem, p. $315 \mathrm{~A}, \mathrm{n}^{\circ}$ 20: «Debet esse utilis in verbo, discretus in silentio, ne aut tacenda proferat, aut dicenda reticescat. 43 distinct. sit rector. in princ. [c. 1, d. 43]. [...] Ecclesiast. 20. Est tacens qui invenitur sapiens, \& est odibilis qui procax est ad loquendum. Est autem tacens non habens sensum loquelae, \& est tacens sciens tempus aptum. Homo sapiens usque ad tempus tacebit, lascivus autem \& imprudens non servabit tempus [Sirach, 20.4-7] \& c. 28. Verbis tuis facito stateram, \& frenos ori tuo rectos, \& attendas ne labaris in lingua, \& cadas in conspectu inimirocum insidiantium tibi, \& sit casus tuus insanabilis in mortem [ibidem, 28.29-30]. [...] In explicanda itaque legatione sua prudenter agat [legatus], ponderet statera prudentiae verba sua. 50 dist. ponderet [c. 14, d. 50], ut eius sermo prius veniat ad limam, quam ad linguam. 2 q. 1 primo [c. 13, C. 2, q. 1] \& q. 6 decreto [c. 11, C. 2, q. 6]».

${ }^{70}$ On the tone of voice, see ibidem, p. 319B, $\mathrm{n}^{\mathrm{o}} 32$ : «Caveaut [legatus] ut in perorando intentionem suam mitissima verborum prolatione proponat [...]. Sed vox eius sit dulcis in loquendo, \& non contentiosa, neque languens neque canora. Canticorum 4 cap. Eloquium tuum dulce [Song of Songs, 4.3] [...]»; and p. 314A, $\mathrm{n}^{\mathrm{o}}$ 18: «In eo [sc. legato] etiam exigitur vox gloriosa [...] ut cum expedit, quod est plurimum moduletur [...] ». On facial expressions, see ibidem, p. 319B, $\mathrm{n}^{\text {os }} 32-33$ : «Et pro his omnibus prudenter agendis discrete componat ante omnia vultum suum, qui liber est, \& litera mentis [...]. Ad hoc autem utile est seipsum in speculo persaepe respicere, \& iuxta rerum explicandarum qualitates, aut suavem, aut saevum, aut mitem, aut asperum, reverendum, aut rigidum, docens se a speculo exhibeat vultum suum». 
contribution was simply to show that, although till now it has been completely ignored by the historiography of diplomacy and international law, this commentary is in fact of great interest to the study of late medieval scholarship on the ambassador. Indeed, it not only deals with some of the most important questions regarding the institutional and material aspects of embassies, in a remarkably elaborate and methodical approach (unknown in other $14^{\text {th }}$ century juridical texts), but it also dedicates considerable space to the objective, cultural and moral qualities of the ambassador, as well as to his behaviour (features which other previous and contemporary texts practically ignore). In so doing, Lucas both anticipates the approach of the tractatus of the following century, who made an effort to systematize the ius commune scholarship on the ambassador, while also actually paying more attention to these qualities and this behaviour than even they were to $\mathrm{do}^{71}$. The brief analysis of the commentary has also shown that, in his reflections on these matters, Lucas goes well beyond the commentary on the constitutions collected in the de legationibus section and offers a wide ranging analysis, both original and independent of Justinian's text, largely built by drawing on sources other than the libri legales: as well as Valerius Maximus, that inexhaustible source of moralizing anecdotes, we find above all Cicero's texts on the orator, and theological and canonical texts, as we have seen, which offer Lucas the starting points from which to draw a profile of a figure which had never before been subject to such a broad and detailed doctrinal analysis. We can thus confirm that which has already frequently been emphasized by scholars: Lucas de Penna's great originality - both in terms of his interests and his approach ${ }^{72}$.

\footnotetext{
${ }^{71}$ See the rubric de legatis, maxime principum of Martino da Lodi's Tractatus de principibus (1442-1447) and the second and third parts of Gonzalo de Villadiego's Tractatus de legato (1485); one may consider also the entries «Ambasiator» in Pietro del Monte's Repertorium utriusque iuris (1453) and in Giovanni Bertachini's Repertorium juris (1481). A separate discussion should be devoted to Bernard de Rosiers' Ambaxiatorum Brevilogum (1435-1436), which however does not fit into the ius commune literature. On these texts, see again D. Fedele, Naissance (supra, n. 5), p. 25-30 and ad indicem.

${ }^{72}$ For some references, see E. Conte, s.v. Luca da Penne (supra, n. 12).
} 